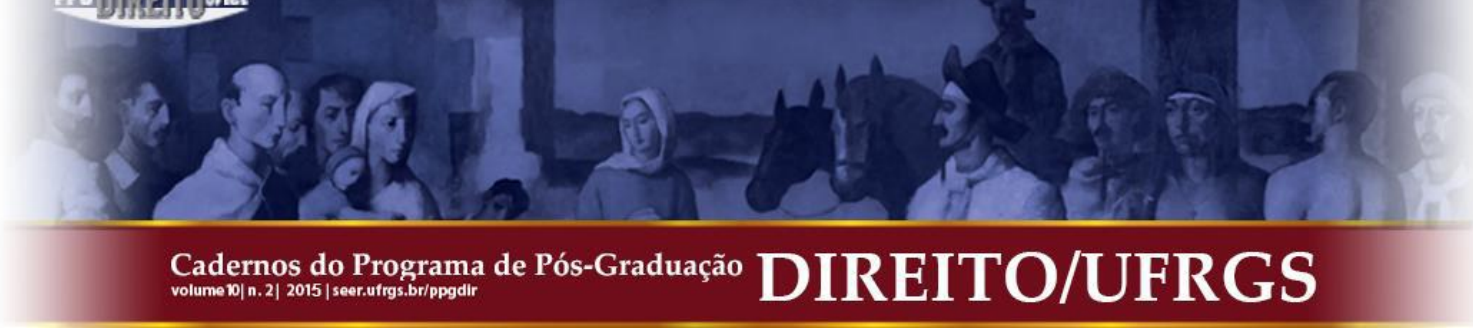

\title{
TEORIA DA NORMA JURÍDICA NO NEOCONSTITUCIONALISMO PÓS- \\ POSITIVISTA: UMA CONCRETIZAÇÃO CONSTITUCIONAL ALÉM DO DECISIONISMO
}

THEORY OF THE LEGAL NORM IN THE POST-POSITIVIST NEOCONSTITUTIONALISM: A CONSTITUTIONAL IMPLEMENTATION BEYOND DECISIONISM

\author{
Heletícia Leão de Oliveira*
}

\begin{abstract}
RESUMO: O presente artigo tem como objeto analisar a teoria da norma jurídica no contexto do neoconstitucionalismo, compreendido como um momento teórico no enfoque pós-positivista. Para tanto, será examinada a distinção entre constitucionalismo e neoconstitucionalismo. Essa discussão implica a análise de importantes marcos filosóficos do Direito, como o positivismo jurídico e o pós-positivismo. Eles influenciaram o ordenamento jurídico criando uma nova percepção da Constituição e de seu papel na interpretação jurídica. Adiante, discute-se as principais diferenças entre a teoria da norma jurídica no positivismo e no pós-positivismo bem como as causas que determinam essas diferenças. Após caracterizar a norma jurídica no pós-positivismo (a distinção em regras e princípios) é analisado se existe um único modelo de normas nesse enfoque teórico. Defende-se a adoção de um modelo de Direito fundado em princípios como algo necessário, mas não excludente do modelo de regras. Por fim, esse estudo examina se o modelo de princípios gera o problema do déficit de racionalidade e uma eventual abertura para o decisionismo. Nesse contexto, afirmase a necessidade de valorização da argumentação jurídica e da racionalidade prática, pois as decisões devem ser devidamente justificadas demonstrando que o resultado alcançado é o mais adequado à ordem jurídica e às peculiaridades do caso.
\end{abstract}

PALAVRAS-CHAVE: Teoria da Norma Jurídica. Pós-Positivismo. Neoconstitucionalismo. Decisionismo Judicial. Argumentação Jurídica. Ponderação.

SUMÁRIO: Introdução. Introdução. 1. Considerações sobre Constitucionalismo e Neoconstitucionalismo. 2. Teoria da Norma Jurídica no Neoconstitucionalista. Considerações finais. Referências.

\section{INTRODUÇÃO}

O positivismo foi desenvolvido da mesma forma que foi operada a ciência moderna. Acreditava-se na ciência pura, realizada por meio de um método específico (raciocínio matemático), que buscava desmistificar a natureza para dominá-la. Portanto, nesse momento as ciências, bem como o saber jurídico, recusavam quaisquer formas de subjetivismo.

\footnotetext{
* Mestre em Direito pelo Centro Universitário Autônomo do Brasil (UniBrasil), Curitiba, Paraná, na área de concentração "Direitos Fundamentais e Democracia". Pós-graduada em Direito Público pela Escola da Magistratura Federal do Paraná (Esmafe). Pesquisadora do Núcleo de Pesquisas em Direito Constitucional da UniBrasil (NupeConst).
} 


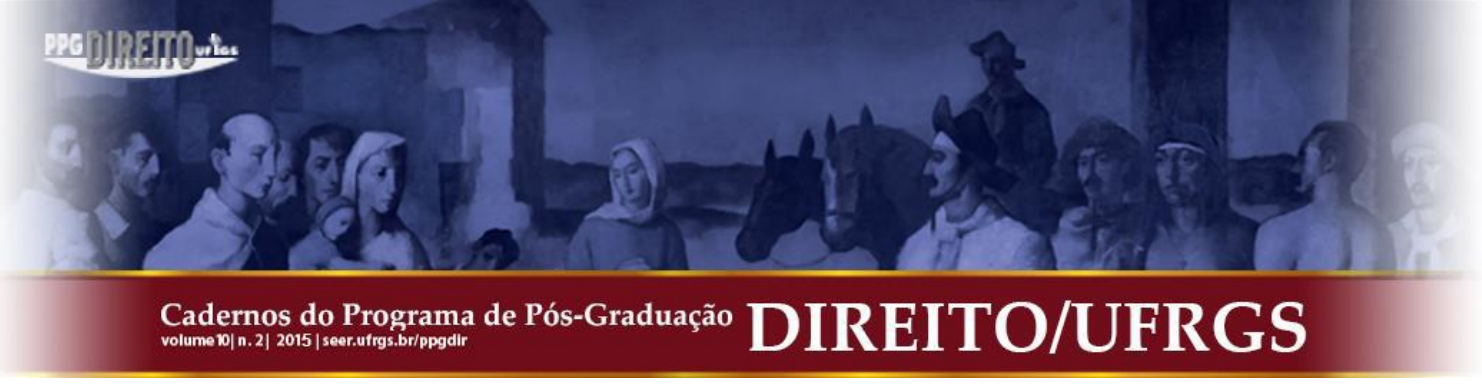

Contudo, esse enfoque jurídico entra em crise, conforme será examinado neste estudo, inclusive pela necessidade de um ordenamento jurídico que não fosse indiferente à valores éticos e à lei como estrutura meramente formal.

Assim, com a superação de modelos jurídicos positivistas, surge a preocupação de buscar soluções adequadas às questões constitucionais. Nesse contexto, a partir da metade do século XX, a maioria das novas Constituições vai incorporar normas de elevado teor axiológico e mecanismos de jurisdição constitucional, assim é implementado o Estado Constitucional. E também ocorre o surgimento de uma nova constelação de ideias, o neoconstitucionalismo. Ele ressalta a centralidade da Constituição no ordenamento jurídico e é caracterizado por negar a tese juspositivista da separação conceitual entre Direito e moral.

Esta referência teórica foi caracterizada, no Brasil (na década de 90), como póspositivista. Afirma-se a incompatibilidade entre positivismo jurídico e Estado de Direito Constitucional. Essa nova filosofia do Direito tem influenciado de maneira decisiva a produção acadêmica e jurisprudencial dos últimos tempos.

Dessa forma, foram afetadas premissas teóricas, filosóficas e ideológicas da interpretação tradicional, inclusive quanto ao papel da norma e do intérprete. Portanto, o momento pós-positivista do neoconstitucionalismo traz uma grande diversidade de questões, impensáveis anteriormente.

\section{CONSIDERAÇÕES SOBRE CONSTITUCIONALISMO E NEOCONSTITUCIONALISMO}

A discussão acerca da distinção entre constitucionalismo e neoconstitucionalismo implica a análise do desenvolvimento de importantes marcos filosóficos do Direito, quais sejam: o positivismo e o pós-positivismo. Neles estão contidos os pensamentos que influenciaram o ordenamento jurídico criando uma nova percepção da Constituição e de seu papel na interpretação jurídica. ${ }^{1}$

Primeiramente, a evolução das ciências naturais, a partir dos finais do século XVIII, e a sua elevação a modelo epistemológico criaram a convicção de que todo o saber válido se devia basear na observação das coisas, da realidade empírica. Assim, a observação e a

\footnotetext{
${ }^{1}$ BARROSO, Luís Roberto. Neoconstitucionalismo e a Constitucionalização do Direito: O Triunfo Tardio do Direito Constitucional no Brasil. Jus Navigandi, Teresina, ano 9, n. 851, 1 nov. 2005, p. 1. Disponível em: http://jus2.uol.com.br/doutrina/texto.asp?id=7547. Acesso em: 10 jun. 2015.
} 


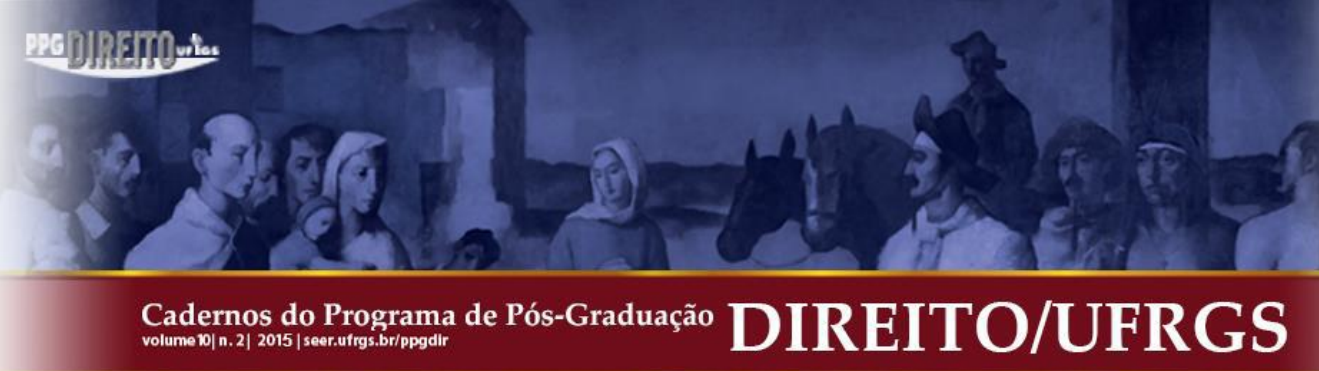

experiência deviam substituir a autoridade e a especulação doutrinária ou filosófica como fontes de saber. ${ }^{2}$

Nesse sentido, Francis BACON, considerado como o fundador da ciência moderna, leciona que "a natureza supera em muito, em complexidade, os sentidos e o intelecto. Todas aquelas belas meditações e especulações humanas, todas as controvérsias são coisas malsãs."3

Por isso, Zygmunt BAUMAN destaca que: "A ciência moderna nasceu da esmagadora ambição de conquistar a natureza e subordiná-la às necessidades humanas."4

Com efeito, a natureza é o que deve ser apreendido matematicamente, fazendo com que o esclarecimento esteja a salvo do retorno do mítico. ${ }^{5}$ Assim, "no trajeto para a ciência moderna, os homens renunciaram ao sentido e substituíram o conceito pela fórmula, a causa pela regra e pela probabilidade.",6

Este espírito atingiu o saber jurídico a partir das primeiras décadas do século XIX. Também este, se quisesse merecer a dignidade de ciência, devia partir de coisas positivas e não de argumentos de autoridade ou de especulações abstratas. ${ }^{7}$

É mister destacar que essa corrente de pensamento é tipicamente oitocentista. Trata-se de uma teoria do século XIX, desenvolvida em um ambiente liberal e pós-revolucionário. E este é o século onde a burguesia se instalou no poder e onde uma outra ordem política é reinante. Por isso, "pode-se dizer que o século XIX é o século burguês.",

Além disso, o referido século “[...] é o século do otimismo com relação aos prodigiosos progressos científicos e tecnológicos que então se verificam, progressos esses sem par na história. O séc. XIX é herdeiro do iluminismo que triunfou, é o século que acredita no homem de modo incondicionado."

Assim sendo, Ricardo Marcelo FONSECA explica que "as ciências naturais e sociais devem limitar-se às explicações causais dos fenômenos de forma objetiva, neutra, livre de

\footnotetext{
${ }^{2}$ HESPANHA, António Manuel. A Cultura Jurídica Europeia: Síntese de um Milênio. Coimbra: Almedina, 2012, p. 398.

${ }^{3}$ BACON, Francis. Novum Organum ou Verdadeiras Indicações Acerca da Interpretação da Natureza. Tradução de José Aluysio Reis de Andrade. Disponível em: http://www.dominiopublico.gov.br/download/texto/cv000047.pdf. Acesso em: 10 out. 2015, p. 7.

${ }^{4}$ BAUMAN, Zygmunt. Modernidade e Ambivalência. Tradução de Marcus Penchel. Rio de Janeiro: Jorge Zahar Editor, 1999, p. 48.

${ }^{5}$ BACON, Francis. op. cit., p. 15.

${ }^{6}$ ADORNO, Theodor W.; HORKHEIMER, Max. Dialética do Esclarecimento. Tradução de Guido de Almeida. Rio de Janeiro: Jorge Zahar, 1985, p. 7.

${ }^{7}$ HESPANHA, António Manuel. op. cit., p. 398.

${ }^{8}$ FONSECA, Ricardo Marcelo. Introdução Teórica à História do Direito. Curitiba: Juruá, 2012, p. 50.
} 


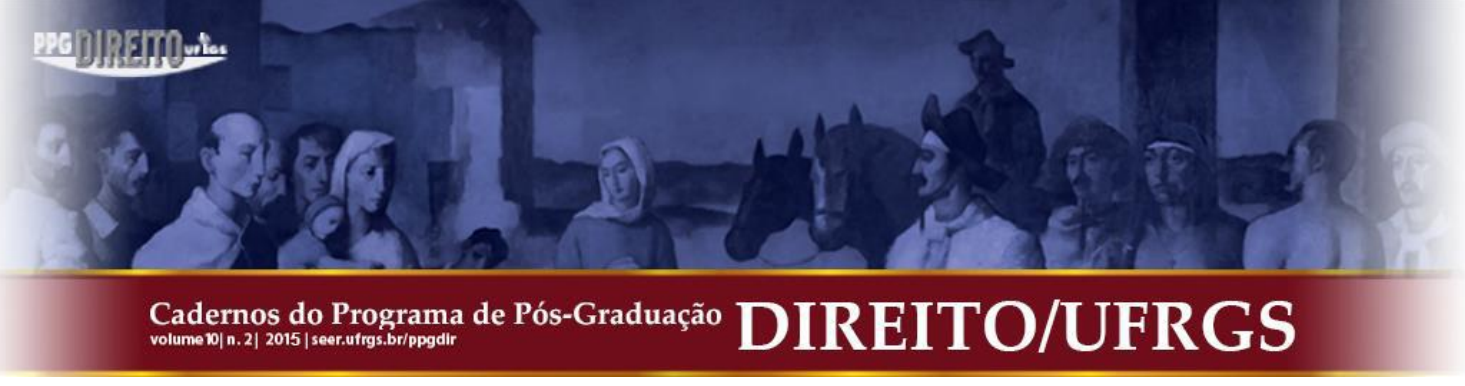

juízos de valores ou ideologias, de noções prévias e preconceitos." 9

O positivismo, em todas as suas formas (legalista, culturalista, sociológico e conceitual $)^{10}$ têm em comum a recusa de quaisquer formas de subjetivismo. O saber jurídico (a ciência jurídica) deveria cultivar métodos objetivos e verificáveis, dela devendo ser excluídas todas as considerações valorativas. Estes juízos de valor em matéria jurídica teriam o seu lugar na filosofia do Direito ou na política do Direito. ${ }^{11}$

Outrossim, o positivismo jurídico aplica os fundamentos do positivismo filosófico no mundo jurídico com o fim de criar uma ciência jurídica com características similares às ciências exatas e naturais. Por isso, a busca da objetividade científica, com ênfase na realidade observável, e não na especulação filosófica, apartou o direito da moral e dos valores transcendentes. ${ }^{12}$

Ademais, a realidade é dotada de exterioridade, ou seja, o objeto existe independentemente do sujeito. Assim, o positivismo pode afirmar que o conhecimento é capaz de abarcar o objeto em sua integralidade representando-o da "maneira como ele é". ${ }^{13}$

Há também uma separação entre fatos e valores. No processo cognitivo, entende-se que os fatos pertencem à ordem do objeto e os valores pertencem à ordem do sujeito. ${ }^{14}$

Tais dualidades possibilitam que o positivismo determine um ideal do saber plenamente objetivo e compreendido como um conhecimento válido. ${ }^{15}$

Além disso, segundo o credo positivista, o Direito vigente é compreendido como um sistema de enunciados jurídicos sem lacunas, por isso questões jurídicas efetivamente em aberto não podem surgir. Cada nova questão jurídica da práxis já foi solucionada pelo sistema, por força da necessidade do pensamento. E essas lacunas devem ser preenchidas, de

\footnotetext{
${ }^{9}$ Idem.

${ }^{10}$ Destaca-se que várias escolas discutem o que significa positivismo. Por isso, António Manuel HESPANHA afirma que é problemático falar em positivismo "puro" sendo mais apropriado referir-se a diferentes positivismos. Assim, "para uns, positiva era apenas a lei, pelo que o saber jurídico tinha de incidir unicamente sobre ela, explicando-a e integrando-a (positivismo legalista). Para outros, positivo era o direito plasmado na vida, nas instituições ou num espírito do povo que se objetivava nas formas quotidianas observáveis de viver o Direito (positivismo culturalista). Positivo era também o seu estudo de acordo com as regras das novas ciências da sociedade, surgidas na segunda metade de século XIX (positivismo sociológico, naturalismo). Finalmente, para outros, positivos eram os conceitos jurídicos, genéricos e abstratos, rigorosamente construídos e concatenados, válidos independentemente da variabilidade da legislação positiva, obedecendo ao novo modelo de ciência como discurso de categorias teoréticas, estabelecido pelo kantismo (positivismo conceitual)." HESPANHA, António Manuel. op. cit., p. 399.

${ }^{11}$ Ibidem, p. 399-400.

${ }^{12}$ BARROSO, Luís Roberto. Curso de Direito Constitucional Contemporâneo: Os Conceitos Fundamentais e a Construção do Novo Modelo. São Paulo: Saraiva, 2013, p. 261-262.

${ }^{13}$ FONSECA, Ricardo Marcelo. op. cit., p. 43-46.

14 Ibidem, p. 48.

${ }^{15}$ Idem.
} 
Esclarecimento é a saída do homem de sua menoridade, da qual ele próprio é culpado. A menoridade é a incapacidade de fazer uso de seu entendimento sem a direção de outro indivíduo. $\mathrm{O}$ homem é o próprio culpado dessa menoridade se a causa dela não se encontra na falta de entendimento, mas na falta de decisão e coragem de servir-se de si mesmo sem a direção de outrem. Sapere aude! Tem coragem de fazer uso de teu próprio entendimento, tal é o lema do esclarecimento. ${ }^{28}$

Para este esclarecimento, o que se exige é liberdade, inclusive a de fazer um uso público de sua razão, em todas as questões. ${ }^{29}$

Com efeito, Theodor W. ADORNO e Max HORKHEIMER, em obra célebre "Dialética do Esclarecimento", lecionam que no positivismo "o programa do esclarecimento era o desencantamento do mundo. Sua meta era dissolver os mitos e substituir a imaginação pelo saber." 30

Essa "unificação da função intelectual, graças à qual se efetua a dominação dos sentidos, a resignação do pensamento em vista da produção da unanimidade, significa o empobrecimento do pensamento bem como da experiência." ${ }^{31}$

Assim, a falência dos valores humanistas se expõe na transformação dos indivíduos em seres genéricos, vazios, iguais uns aos outros pelo isolamento na coletividade, dominada pela força. A dominação da natureza se converteu em dominação sobre os homens. ${ }^{32}$

O esclarecimento, sustentado pelo projeto iluminista que buscou redimir o mundo pelo conhecimento, através da razão, "forjou, ao contrário, uma sociedade repressora e totalitária. O processo de racionalização que sustenta a filosofia e a ciência, em lugar de libertar os homens, proporcionou-lhes o controle, a dominação pelo cálculo." 33

Hoje, defende-se que é preciso superar toda razão absoluta, fechada e auto-suficiente, pois temos que considerar a possibilidade de evolução da razão. ${ }^{34}$

Além disso, Edgar MORIN leciona que o progresso científico produz potencialidades tanto benéficas quanto subjugadoras ou mortais (ideia de ambivalência). Desde os bombardeamentos de Hiroxima e Nagasaki sabe-se que "[...] a energia atômica significa

\footnotetext{
${ }^{28}$ KANT, Imamnuel. Resposta à Pergunta: Que é "Esclarecimento" (Aufklärung)? Textos Seletos. Tradução de Floriano de Sousa Fernandes. 2. ed. Petrópolis: Vozes, 1985, p. 100.

${ }^{29}$ Ibidem, p. 104.

30 ADORNO, Theodor W.; HORKHEIMER, Max. Dialética do Esclarecimento. Tradução de Guido de Almeida. Rio de Janeiro: Jorge Zahar, 1985, p. 6.

${ }^{31}$ Ibidem, p. 20.

${ }^{32}$ BORGES, Juliano. op. cit., p. 103-105.

${ }^{33}$ Ibidem, p. 103.

${ }^{34}$ MORIN, Edgar. op. cit., p. 166.
} 


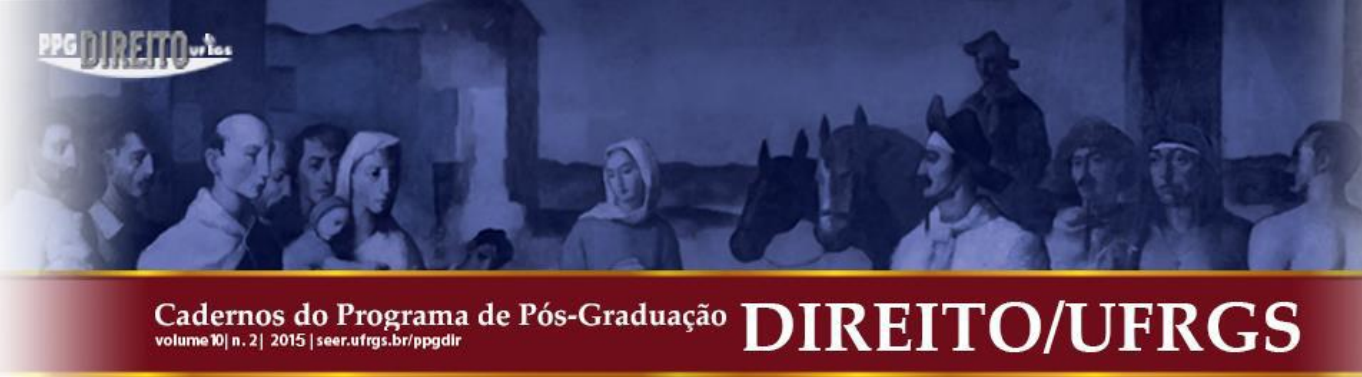

potencialidade suicida para a humanidade; sabemos que, mesmo pacífica, ela comporta perigos biológicos, sociais e políticos."

Neste contexto, o referido doutrinador explica que há um "progresso inédito dos conhecimentos científicos, paralelo ao progresso múltiplo da ignorância; progresso dos aspectos benéficos da ciência, paralelo ao progresso de seus aspectos nocivos ou mortíferos; progresso ampliado dos poderes da ciência, paralelo à impotência ampliada dos cientistas a respeito desses mesmos poderes.",35

Ainda, “[...] o conhecimento não é um resultado "puro" de uma operação que busca "refletir" o objeto, mas um processo complexo no qual o sujeito interfere decisivamente na construção do resultado final de uma pesquisa científica."36

Outrossim, Niels BOHR e Werner HEISENBERG demonstraram que não é possível observar um objeto sem interferir nele, sem o alterar, e a tal ponto que o objeto que sai de um processo de medição não é o mesmo que lá entrou. ${ }^{37}$

E também foi questionado o rigor da matemática, pois sendo ela “[...] o grande pilar da ciência moderna, vê-se impossibilitada de fazer aquilo que sua essência lhe impõe, encontrar respostas para tudo de forma exata."38

Assim, devido as ideias ora expostas, ao fim da Segunda Guerra Mundial, a doutrina consentiu com a ideia de que um ordenamento jurídico indiferente a valores éticos e da lei como uma estrutura meramente formal, não podiam mais ser sustentadas. ${ }^{39}$

Este momento produziu um sentimento de desconfiança nos postulados da neutralidade e da formalidade da lei geral e abstrata, inerentes à conformação do Estado de Direito legislativo, pois esses princípios tornaram-se incapazes de acompanhar e realizar as pretensões e finalidades da ampliação das funções do Estado advindas do politeísmo de valores imerso nos processos sociais. ${ }^{40}$

Com efeito, a partir da metade do século XX, a maioria das novas Constituições vai incorporar normas impregnadas de elevado teor axiológico e mecanismos de jurisdição

\footnotetext{
${ }^{35}$ Ibidem, p. 18-19.

${ }^{36}$ SANTOS, Boaventura de Souza. A Crítica da Razão Indolente: Contra o Desperdício da Experiência. 4. ed. v. 1. São Paulo, Cortez, 2002, p. 60.

${ }^{37}$ Ibidem, p. 69.

${ }^{38}$ Ibidem, p. 70.

${ }^{39}$ BARROSO, Luís Roberto. op. cit. (2013), p. 264.

${ }^{40}$ RAMOS, Écio Oto; POZZOLO, Susanna. Neoconstitucionalismo e Positivismo Jurídico: As Faces da Teoria do Direito em Tempos de Interpretação Moral da Constituição. São Paulo: Landy Editora, 2006, p. 16.
} 


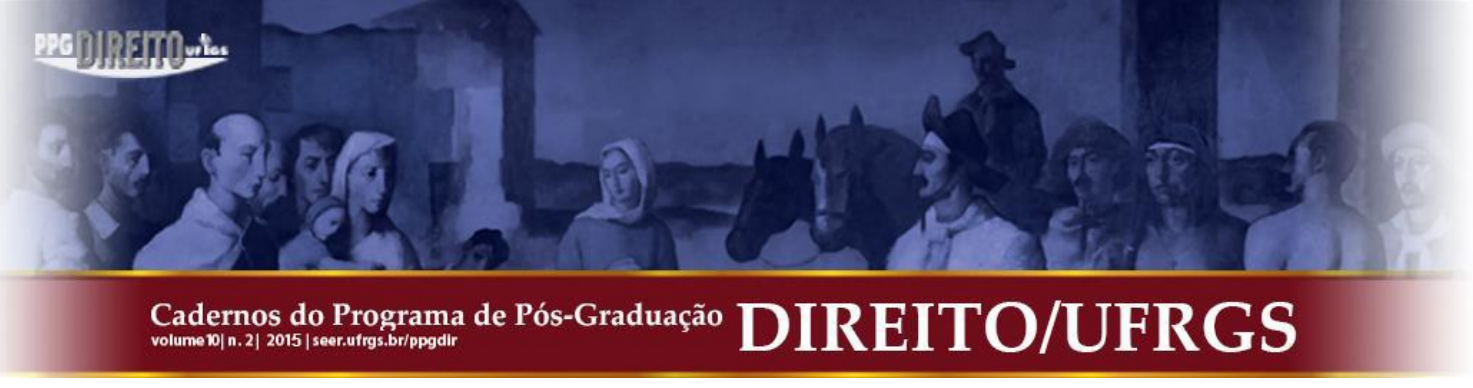

Ao lado do positivismo que se desenvolve no Estado Legislativo de Direito, o neoconstitucionalismo origina-se no Estado Constitucional de Direito. Ao invés de uma teoria de fontes do Direito focada no código e na lei formal, ele ressalta a centralidade da Constituição no ordenamento jurídico, a ubiquidade de sua influência na ordem jurídica e o papel criativo da jurisprudência. ${ }^{47}$

Como principais caraterísticas do neoconstitucionalismo citam-se cinco epígrafes: “mais princípios do que regras, mais ponderação do que subsunção, onipresença da Constituição em todas as áreas jurídicas e em todos conflitos relevantes, espaços isentos de opinião legislativa, onipotência judicial no lugar da autonomia do legislador ordinário e a coexistência de uma constelação plural de valores."

Ademais, a incorporação de valores na forma de direitos fundamentais determinaria a inseparabilidade do valor ético sobre o conteúdo meramente jurídico da Constituição determinando a especialidade desse documento e requerendo uma interpretação moral do texto fundamental. ${ }^{49}$

Assim sendo, a teoria neoconstitucionalista propõe um certo modelo teórico para a explicação e descrição do Direito do Estado Constitucional, caracterizado por negar a tese juspositivista da separação conceitual entre Direito e moral. ${ }^{50}$

Ademais, poderia se pensar que as Constituições neoconstitucionalistas são um despropósito, devido a existência de antinomias. Tratam-se de "[...] um conjunto de normas contraditórias entre si, que se sobrepõem de modo permanente, dando lugar a soluções dispares." 51

Luis PRIETO SANCHÍS explica que isto se sucederia se as normas constitucionais agissem como regras mas, na lógica do neoconstitucionalismo, os princípios predominam sobre as regras e são baseados pela técnica da ponderação. ${ }^{52}$

Além disso, a técnica da subsunção não se aplica aos princípios e direitos constitucionais que apresentam, de forma aberta, o suposto direito ou condição de aplicação.

\footnotetext{
${ }^{47}$ SARMENTO, Daniel. O Neoconstitucionalismo no Brasil: Riscos e Possibilidades. In: SARMENTO, Daniel (coord.). Filosofia e Teoria Constitucional Contemporânea. Rio de Janeiro: Lúmen Júris, 2009, p. 120.

${ }^{48}$ PRIETO SANCHÍS, Luis. op. cit., p. 117.

49 POZZOLLO, Susanna. Um Constitucionalismo Ambíguo. In: CARBONELL, Miguel. Neoconstitucionalismo(s). Trotta: Madrid, 2003, p. 198.

${ }^{50}$ Ibidem, p. 188.

${ }^{51}$ PRIETO SANCHÍS, Luis. op. cit., p. 126.

${ }^{52}$ Idem.
} 


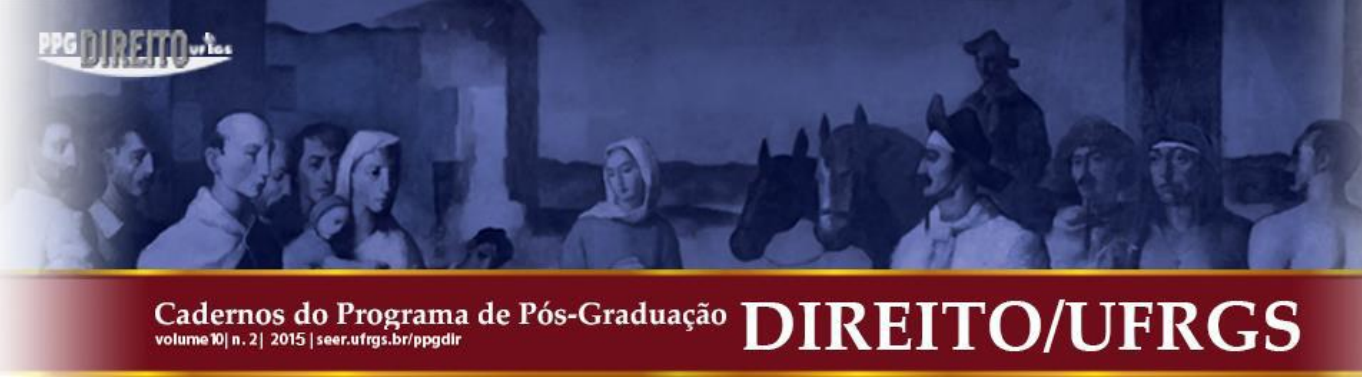

Assim, a tradicional interpretação positivista é insuficiente para o marco do neoconstitucionalismo. ${ }^{53}$

Posto isso, Écio Oto RAMOS afirma que as tentativas de concretizar a Constituição têm fomentado à doutrina na formulação de diferentes concepções sobre o entendimento em torno do neoconstitucionalismo. ${ }^{54}$

Por isso, Humberto ÁVILA leciona que a diversidade de autores, concepções, elementos e perspectivas torna impossível traçar uma teoria única do neoconstitucionalismo utilizando no seu lugar a expressão plural "neoconstitucionalismo(s)." 55

Ademais, segundo Paulo Ricardo SCHIER o neoconstitucionalismo “[...] não substancia, organicamente, uma nova teoria constitucional ou um movimento doutrinário, senão um momento teórico em que os constitucionalistas buscam a superação de modelos jurídicos positivistas e soluções mais adequadas as questões constitucionais diante da insuficiência do positivismo." 56

É mister destacar que não se pode negar que a maior parte das premissas referenciais que marcam o neoconstitucionalismo foram construídas dentro do próprio constitucionalismo. Assim, a mudança de objeto por meio do qual as Constituições passaram a albergar mais direitos sociais e uma maior pluralidade axiológica ocorreu ainda no contexto temporal do constitucionalismo. Também o processo de reaproximação entre Direito e moral, desencadeado após a crise institucional decorrente da Segunda Grande Guerra, aponta que foi no constitucionalismo que se desenvolveu esta premissa do neoconstitucionalismo. Ainda, as críticas a um modelo de norma fundado exclusivamente sob a estrutura de regras foi, igualmente, desencadeada no âmbito do constitucionalismo. ${ }^{57}$

Nesse sentido, Paulo Ricardo SCHIER afirma que "assiste razão à crítica ${ }^{58}$ que afirma que tudo o que se designa como características tipificadoras do neoconstitucionalismo já haviam sido desenvolvidas, de algum modo, no seio do constitucionalismo. Todavia aquele

\footnotetext{
${ }^{53}$ Ibidem, p. 126-127.

${ }^{54}$ RAMOS, Écio Oto; POZZOLO, Susanna. op. cit., p. 24

55 ÁVILA, Humberto. "Neoconstitucionalismo": Entre a "Ciência do Direito" e o "Direito da Ciência". In: SOUZA NETO, Cláudio Pereira de; SARMENTO, Daniel; BINENBOJM, Gustavo (coords.). Vinte Anos da Constituição Federal de 1988. Rio de Janeiro: Lumen Juris, 2009, p. 187. Acerca desse tema, veja: CARBONELL, Miguel. Neoconstitucionalismo(s). Madrid: Editorial Trotta, 2003.

${ }^{56}$ SCHIER, Paulo Ricardo. Novos Desafios da Filtragem Constitucional no Momento do Neoconstitucionalismo. In: NETO, Cláudio Pereira de Souza; SARMENTO, Daniel (coords.). A Constitucionalização do Direito: Fundamentos Teóricos e Aplicações Específicas. Rio de Janeiro: Lumen Juris, 2007, p. 254.

${ }^{57}$ SCHIER, Paulo Ricardo. op. cit. (2014), p. 51.

58 DIMOULIS, Dimitri. Uma Visão Crítica do Neoconstitucionalimo. In: SALOMÃO, George Leite; SALOMÃO, Glauco Leite (coords.). Constituição e Efetividade Constitucional. Salvador: Juspodivm, 2008.
} 


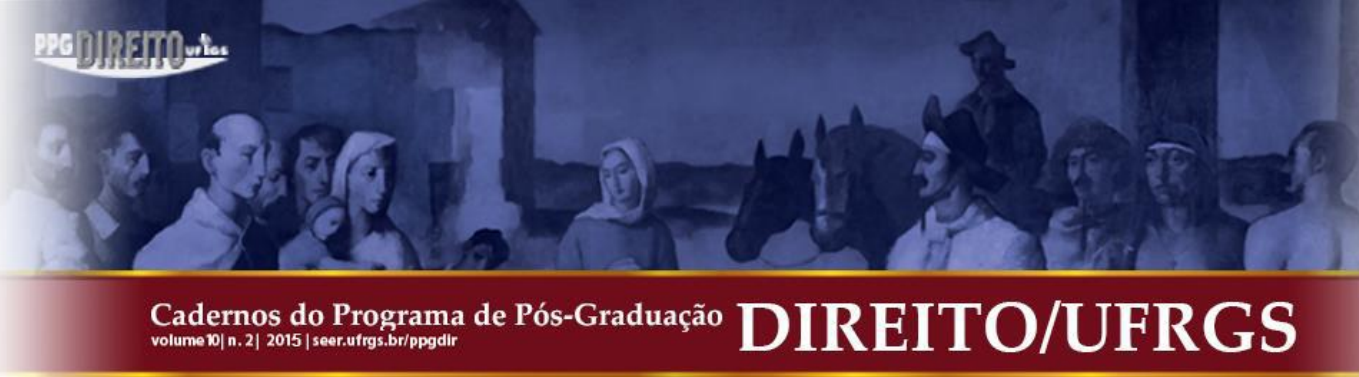

somente se apresenta como tal, como um novo momento, quando todos os elementos que o caracterizam se agrupam."

Com efeito, imperioso o desenvolvimento do neoconstitucionalismo compreendido como um novo quadro de referência capaz de dar conta das significativas mudanças acarretadas pela implementação do Estado Democrático Constitucional contemporâneo.

Além disso, esta constelação teórica, na década de 90, foi caracterizada como póspositivista, isto é, como uma nova filosofia do Direito que tem influenciado de maneira decisiva a produção acadêmica e jurisprudencial dos últimos tempos. ${ }^{60}$

O uso do termo pós-positivista para designar a configuração contemporânea do pensamento jurídico implica, necessariamente, a ruptura com o positivismo jurídico. Logo, há a superação das ideias básicas desse último, tais como: a separação entre Direito e moral e a defesa da teoria das fontes sociais do Direito. ${ }^{61}$

Ana Paula de BARCELLOS e Luís Roberto BARROSO afirmam que pós-positivismo é “[...] a designação provisória e genérica de um ideário difuso, no qual se incluem o resgate dos valores, a distinção qualitativa entre princípios e regras, a centralidade dos direitos fundamentais e a reaproximação entre Direito e ética.",62

Portanto, ficam evidenciadas as principais diferenças entre constitucionalismo e neoconstitucionalismo bem como positivismo e pós-positivismo. $\mathrm{O}$ intuito foi demonstrar o desenvolvimento dos pressupostos do momento pós-positivista do neoconstitucionalismo, visto que este traz uma grande diversidade de questões, impensáveis anteriormente, conforme se verá adiante. Feitas essas considerações, será analisada a teoria da norma jurídica nos contextos positivista e pós-positivista.

\footnotetext{
${ }^{59}$ SCHIER, Paulo Ricardo. op. cit. (2014), p. 52.

${ }^{60}$ BARROSO, Luís Roberto. op. cit. (2013), p. 264.

${ }^{61}$ MAIA, Antonio Cavalcanti. Nos Vinte Anos da Carta Cidadã: Do Pós-positivismo ao Neoconstitucionalismo. In: SOUZA NETO, Cláudio Pereira de; SARMENTO, Daniel; BINENBOJM, Gustavo (coords.). Vinte Anos da Constituição Federal de 1988. Rio de Janeiro: Lumen Juris, 2009, p. 122.

${ }^{62}$ BARROSO, Luis Roberto; BARCELLOS, Ana Paula de. A Nova Interpretação Constitucional: Ponderação, Argumentação e Papel dos Princípios. In: LEITE: George Salomão (org.). Dos Princípios Constitucionais: Considerações em Torno das Normas Principiológicas da Constituição. São Paulo: Malheiros: 2003, p. 134.
} 


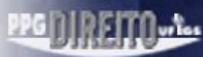

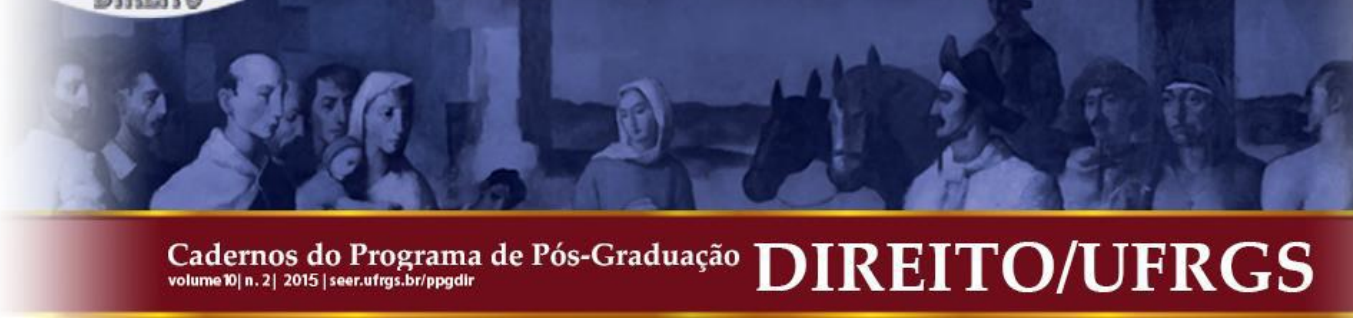

\section{TEORIA DA NORMA JURÍDICA NO CONTEXTO POSITIVISTA E PÓS- POSITIVISTA}

No positivismo, a aplicação do Direito limitava-se a um programa lógico de subsunção entre descrição normativa e realidade, pois a concepção de norma se reduzia ao enunciado linguístico. Assim, a norma era a descrição abstrata de um fato, com imputação de consequências, feita pelo Estado. Diante disso, a interpretação da norma se referia à decodificação de enunciados linguísticos e, logo, tinha-se uma identidade entre norma e texto de norma, sendo esta última o texto a ser interpretado. ${ }^{63}$

O mecanismo lógico deste modelo normativo [...] "funcionava com facilidade diante das regras, pois era possível identificar o que estava permitido, proibido ou obrigado a se fazer. Dessa forma, era evidente a identificação da conduta a ser levada a efeito." ${ }^{64}$

Além disso, o intérprete desempenharia a função técnica de identificar a norma aplicável, de revelar o seu sentido e fazê-la incidir sobre os fatos do caso levado a sua apreciação. Nesse momento positivista, acreditava-se na objetividade da atividade interpretativa e na neutralidade do intérprete. ${ }^{65}$

Entretanto, o processo de subsunção estritamente formal não funcionava diante de enunciados dotados de elevada carga axiológica, baixa densidade normativa e alto grau de indeterminação e abstração. Por isso, o positivismo retirou dos princípios a sua normatividade colocando-os como "cano de escape" do ordenamento jurídico já que eles não se enquadravam em sua lógica. ${ }^{66}$

Dessa forma, os princípios desempenhavam uma importante função supletiva, integradora e corretiva das regras jurídicas. Eles operavam para aperfeiçoar o ordenamento jurídico e entrariam em jogo quando outras normas não estivessem em condição de desempenhar de forma satisfatória a função reguladora que lhe foi atribuída. ${ }^{67}$

Gustavo ZAGREBELSKY leciona que "a incidência direta dos princípios sobre a realidade, ou seja, a possibilidade de conferir aos direitos um valor normativo próprio, é algo não apenas não previsto, senão excluído pelo positivismo jurídico". ${ }^{68}$

\footnotetext{
${ }^{63}$ SCHIER, Paulo Ricardo. Direito Constitucional: Anotações Nucleares. 8. tir. Curitiba: Juruá, 2008, p. 98.

${ }^{64}$ Idem.

${ }^{65}$ BARROSO, Luís Roberto. op. cit. (2013), p. 331.

${ }^{66}$ SCHIER, Paulo Ricardo. op. cit. (2008), p. 98-99.

67 ZAGREBELSKY, Gustavo. op. cit., p. 117.

${ }^{68}$ Ibidem, p. 118.
} 


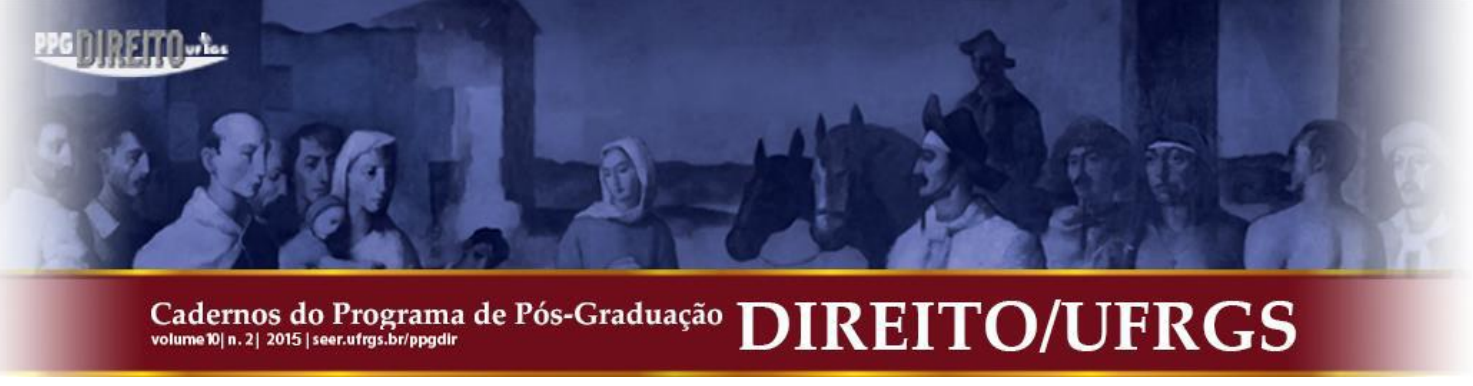

Portanto, era preciso superar os modelos tradicionais propugnados pelo positivismo jurídico impondo uma visão que também comportasse a normatividade dos princípios. ${ }^{69}$

Contudo, não se pode deixar de reconhecer as contribuições do positivismo jurídico à estrutura da norma jurídica, bem como a sua preocupação com a clareza, a certeza e a objetividade no estudo do Direito. $^{70}$

O momento pós-positivista do neoconstitucionalismo afirma a normatividade e vinculatividade dos princípios assentando-os como valores jurídicos supremos da sociedade e servindo de parâmetro de aplicação do Direito para o Estado e a sociedade civil. Logo, não se trata de um Direito justo à luz de valores metafísicos ou formais, mas sim de uma reserva histórica de Justiça (padrão de justiça eleito por determinada sociedade em dado momento). ${ }^{71}$

Por isso, na fase pós-positivista, os princípios passam a caracterizar o "coração das Constituições", irradiando-se por todas as questões jurídicas. ${ }^{72}$

Nesse contexto, Friedrich MÜLLER concebe uma teoria estruturante do Direito, ${ }^{73}$ em face da concepção positivista de norma jurídica, que leva em consideração os elementos que efetivamente contribuem para a formulação da decisão. ${ }^{74}$

Segundo este doutrinador, é preciso compreender a concretização da norma como um processo estruturado. Neste modelo, vê-se que elementos da realidade (contexto, caso concreto e a pré-compreensão do interprete) são determinantes para a realização do Direito. Assim, a carga axiológica dos princípios pode ter realização normativa para além do simples processo de subsunção formal. ${ }^{75}$

Ademais, pode-se dizer que não há identidade entre o texto da norma e a norma, visto que o teor literal de uma prescrição juspositiva é apenas a "ponta do iceberg". Logo, a norma não seria o ponto de partida da interpretação, senão o produto final desta atividade, ou seja, do produto da interpretação dos enunciados linguísticos jurídicos (de regras e princípios) diante de um caso concreto. ${ }^{76}$

Com efeito, Luís Roberto BARROSO explica que a percepção do fenômeno não era suficiente, por si só, para tornar efetiva a distinção entre regras e princípios. O tema teve um

\footnotetext{
${ }^{69}$ SCHIER, Paulo Ricardo. op. cit. (2008), p. 99.

${ }^{70}$ MAIA, Antonio Cavalcanti op. cit., p. 123.

${ }_{71}^{71}$ SCHIER, Paulo Ricardo. op. cit. (2007),p. 259.

72 Idem.

${ }^{73}$ MULLER, Friedrich. op. cit. (2000), p. 68-69.

${ }^{74}$ MULLER, Friedrich. Tesis acerca de la Estrutura de las Normas Jurídicas. Tradução de Luis Villacorta Mancebo. Madrid: Centro de Estudios Constitucionales, 1989, p. 112.

${ }^{75}$ SCHIER, Paulo Ricardo. op. cit. (2008), p. 100.

${ }^{76}$ Ibidem, p. 98.
} 


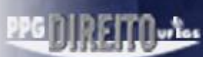

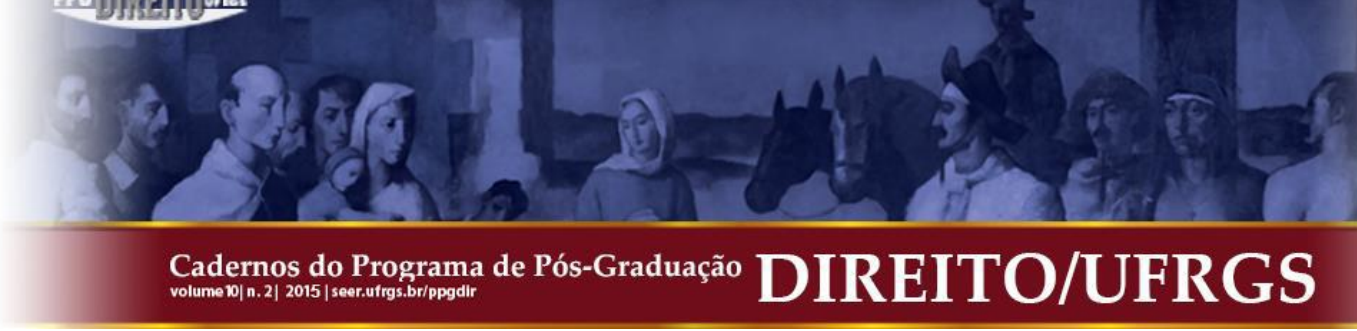

desenvolvimento mais apurado, no Brasil, com a divulgação das ideias de Ronald DWORKIN, a partir do final da década de 80, e ao longo da década de 90, por Robert ALEXY. ${ }^{77}$

Ronald DWORKIN, ao analisar a estrutura das normas jurídicas, leciona que:

\begin{abstract}
As regras são aplicáveis à maneira do tudo ou nada. Dados os fatos que uma regra estipula, então ou a regra é válida, e neste caso a resposta que ela fornece deve ser aceita, ou não é válida, e neste caso em nada contribui para a decisão. [...] os princípios contêm razões que indicam uma direção e eles possuem uma dimensão do peso ou importância, que as regras não têm. Assim, no conflito entre princípios, o intérprete deve considerar a força relativa de cada um. ${ }^{78}$
\end{abstract}

Com efeito, Robert ALEXY, apesar de não se auto-classificar explicitamente como pós-positivista, denomina a sua teoria de não positivista sendo seu posicionamento uma crítica ao positivismo hermenêutico, de matriz analítica, de Herbert HART. ${ }^{79}$

Este doutrinador sustenta que a diferenciação entre regras e princípios é uma das colunas mestras do edifício da teoria dos direitos. Assim, "os princípios são mandamentos de otimização que são caracterizados por poderem ser satisfeitos em graus variados. Eles são normas que ordenam que algo seja realizado na maior medida possível dentro das possibilidades jurídicas e fáticas existentes. Por isso, os princípios não contêm um mandamento definitivo, mas apenas prima facie.“

E ele também explica que "as regras são normas que são sempre ou satisfeitas ou não satisfeitas. Se uma regra é válida deve ser feito exatamente aquilo o que ela ordena (impõe, permite, autoriza ou proíbe uma conduta), nem mais e nem menos."

Portanto, a superação do Estado de Direito Legislativo resultou em importantes consequências jurídicas visto que "a separação da lei e a separação dos direitos e da justiça têm enorme relevância a uma distinção estrutural das normas jurídicas que no Estado Constitucional deve ser muito mais valorizada do que foi na anterioridade. Assim, dentro de uma noção genérica de norma jurídica, está a importante distinção entre regras e princípios.”81

\footnotetext{
${ }^{77}$ BARROSO, Luís Roberto. op. cit. (2013), p. 227.

${ }^{78}$ DWORKIN, Ronald. Levando os Direitos a Sério. Tradução de Nelson Boeira. São Paulo: Martins Fontes, 2002, p. 24-26 e 39-42.

${ }^{79}$ DWORKIN, Ronald. El Concepto y la Validez del Derecho y Outros Ensayos. Barcelona: Gedisa, 2004 , p. 61.

${ }^{80}$ ALEXY, Robert. Teoria dos Direitos Fundamentais. 2. ed. Tradução de Virgílio Afonso da Silva. São Paulo: Malheiros, 2011, p. 85-104.

${ }^{81}$ ZAGREBELSKY, Gustavo. op. cit., p. 109.
} 


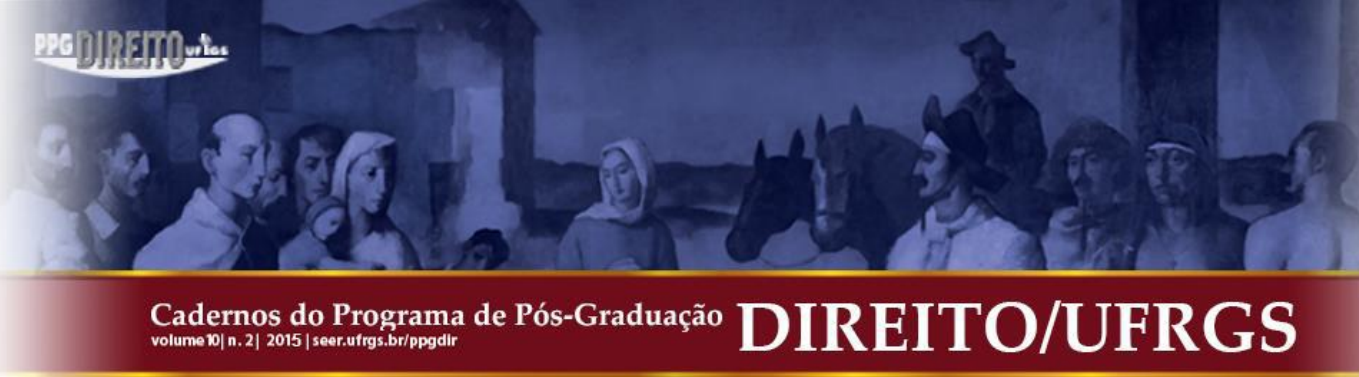

Nesse contexto, é mister indagar se existe um único modelo de normas, diferenciadas em regras e princípios, no contexto pós-positivista.

Uma possibilidade é o modelo puro de regras que é mais atraente do ponto de vista da vinculação ao texto constitucional, da segurança jurídica e da previsibilidade. Os defensores desse modelo entendem que as normas de direitos fundamentais são livres de sopesamento sendo necessária a interpretação dessas disposições. ${ }^{82}$

Gustavo ZAGREBELSKY explica que se o Direito estivesse composto apenas de regras, aplicadas mecânica e passivamente, ocorreria a maquinização de sua aplicação por meio de pensadores autônomos, aos quais se proporcionaria o Direito e eles dariam a resposta. Assim, "tal ideia, tipicamente positivista, carece totalmente de sentido na medida em que o Direito contenha princípios cuja aplicação é distinta e requer que, quando a realidade exija uma reação dos indivíduos, se tome posição ante a esta de conformidade com aqueles princípios." $" 83$

No mesmo sentido, Paulo Ricardo SCHIER leciona a absoluta impossibilidade de existência de um sistema formado apenas por regras, pois não existiriam critérios seguros para a solução de colisões e resolução de casos difíceis. ${ }^{84}$

O modelo proposto por Eike Von HIPPEL é um modelo puro de princípios no qual as normas de direitos fundamentais são normas de princípios que indicam que, na ordenação das relações sociais e na solução de conflitos, deve ser conferido um peso especial a determinados interesses de liberdade (liberdades de crença, opinião, profissão e propriedade). ${ }^{85}$

A esse respeito, há quem afirme que não seria possível a existência de um sistema formado apenas por princípios diante da grande imprecisão de seus enunciados, o que geraria dúvidas sobre a exata forma de agir nas situações concretas. ${ }^{86}$

A principal objeção a esse modelo sustenta que ele não levaria a sério a Constituição escrita, pois ele passaria a largo da regulação diferenciada que a Constituição alemã contém sobre restrições a direitos fundamentais. ${ }^{87}$

\footnotetext{
${ }^{82}$ ALEXY, Robert. op. cit. (2011), p. 123.

${ }^{83}$ ZAGREBELSKY, Gustavo. op. cit., p. 111.

${ }^{84}$ SCHIER, Paulo Ricardo. op. cit. (2008),p. 104.

${ }^{85}$ ALEXY, Robert. op. cit. (2011), p. 121.

${ }^{86}$ SCHIER, Paulo Ricardo. op. cit. (2008),p. 104.

${ }^{87}$ ALEXY, Robert. op. cit. (2011), p. 121.
} 


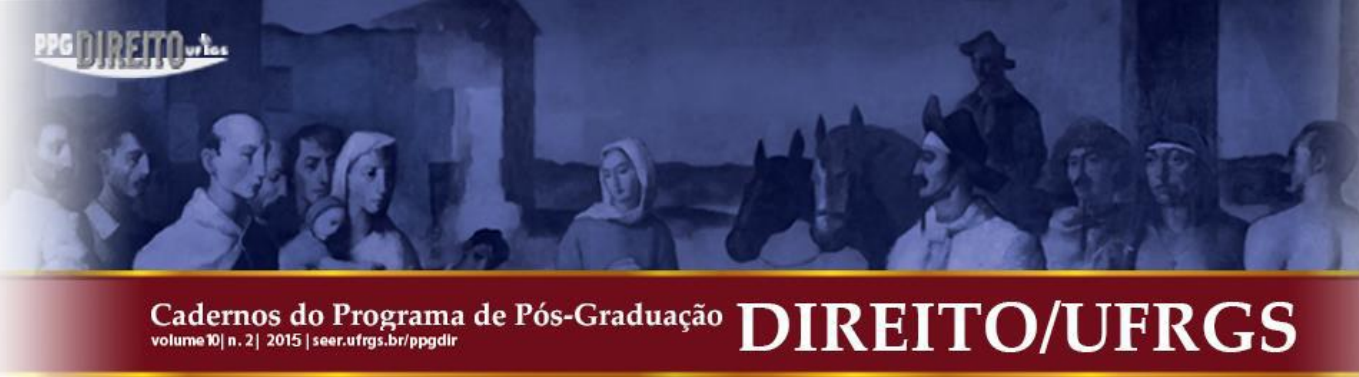

Robert ALEXY entende que quando duas formas puras e antagônicas não são aceitáveis, deve-se considerar a possibilidade de uma forma mista ou combinada. Esse modelo é composto pela ligação entre um nível de princípios e de regras. Portanto, ele defende que "um modelo adequado é obtido somente quando às disposições de direitos fundamentais são atribuídos tanto regras quanto princípios. Ambos são reunidos em uma norma constitucional de caráter duplo." 88

Este também é o entendimento de Paulo Ricardo SCHIER para quem o sistema jurídico necessita de regras e princípios que desempenham diversas funções. ${ }^{89}$

Ainda, Marçal JUSTEN FILHO explica que a existência da regra é essencial para a segurança jurídica e para a certeza do Direito, pois ela traduz escolhas, valores e fatos sociais permitindo a todos os integrantes da sociedade conhecer de antemão a solução prestigiada pelo Direito. $^{90}$

Ademais, "a ampliação da influência dos princípios produz a redução da certeza do Direito, tal como aumentar a importância das regras poderá conduzir à cristalização da disciplina jurídica e sua inadequação para regular a vida social. É evidente que a aplicação das regras deve ser permeada pela influência dos princípios, mas não se pode eliminar a certeza, que é inerente à regra." Logo, tornou-se pacífico entre os estudiosos o reconhecimento de que o Direito é um conjunto de normas jurídicas configuráveis como princípios e regras. ${ }^{91}$

Portanto, no pós-positivismo existem três modelos que tratam da estrutura da norma jurídica: modelo puro de regras, modelo puro de princípios e o modelo de regras e princípios. Diante de critérios como segurança jurídica, previsibilidade, imprecisão dos enunciados por princípios e a maquinização da disciplina jurídica por regras, entende-se a adoção de um modelo de Direito fundado em princípios como algo necessário e não excludente do modelo de regras. Logo, o modelo ideal é o misto fundado tanto em princípios como em regras que desempenham funções distintas no ordenamento jurídico.

\footnotetext{
${ }^{88}$ Ibidem, p. 144.

${ }^{89}$ SCHIER, Paulo Ricardo. op. cit. (2008),p. 104.

90 JUSTEN FILHO, Marçal. Curso de Direito Administrativo. 5. ed. São Paulo: Saraiva, 2010, p. 55.

${ }^{91}$ Ibidem, p. 50-55.
} 


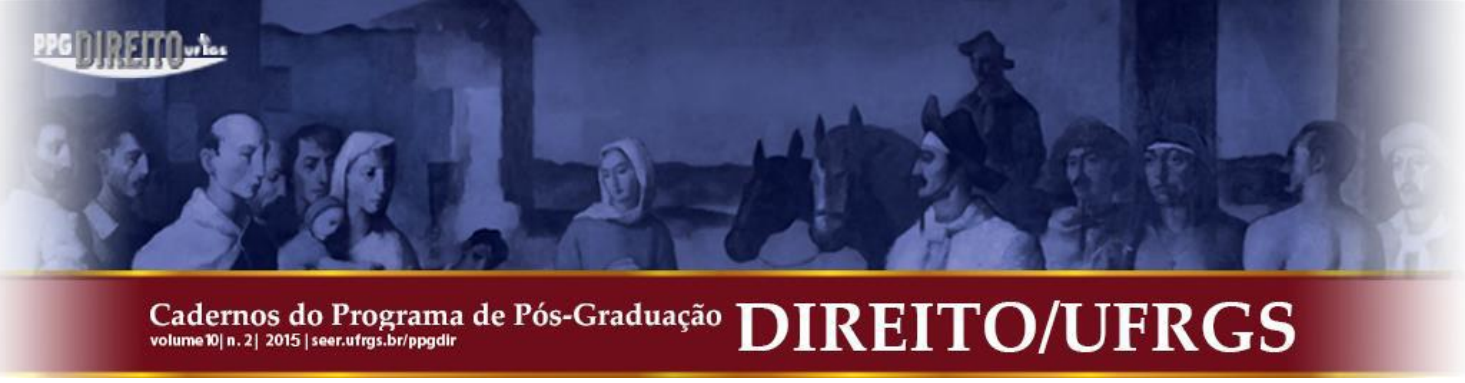

com a produção de uma conclusão). Todo esse processo intelectual tem como parâmetro o princípio da proporcionalidade ou razoabilidade. ${ }^{96}$

Ana Paula de BARCELLOS também trata do modelo de ordenação técnica da ponderação (requisitos da universalidade, coerência e consistência e consequencialista) com o intuito de identificar com maior clareza as etapas que o intérprete deve percorrer ao empregá$1 \mathrm{a}{ }^{97}$

Há quem vislumbre a ponderação como um princípio autônomo. Ricardo Lobo TORRES sustenta que "a ponderação deixou de ser apenas um método de aplicação do Direito para tornar-se um verdadeiro princípio jurídico, que proclama um estado de coisas a ser atingido: o estado de coisas resultado da ponderação." 98

Contudo, muitas críticas ${ }^{99}$ são feitas à técnica da ponderação. Este artigo analisa a alegação de que lhe faltam critérios racionais de decidibilidade. Segundo essa linha crítica, o sopesamento nada mais é que um decisionismo disfarçado. ${ }^{100}$

Nesse contexto, "o intérprete torna-se coparticipante do processo de criação do Direito, completando o trabalho do constituinte ou do legislador, ao fazer valorações de sentido em cláusulas abertas e ao realizar escolher entre soluções possíveis. Como consequência sua pré-compreensão de mundo irá influenciar [...] os valores sociais que irão embasar suas decisões." 101

Daniel SARMENTO trata dos problemas de uma hermenêutica constitucional que tenha como norte as pré-compreensões do intérprete. Ele explica que "quando se passa da descrição para a prescrição, a aposta na pré-compreensão como limite para o decisionismo

\footnotetext{
${ }^{96}$ BARROSO, Luís Roberto. op. cit. (2013), p. 361-363.

${ }^{97}$ BARCELLOS, Ana Paula de. op. cit., p. 91-92.

98 TORRES, Ricardo Lobo. A Legitimação dos Direitos Humanos e os Princípios da Ponderação e da Razoabilidade. In: TORRES, Ricardo Lobo. (coord.). Legitimação dos Direitos Humanos. Rio de Janeiro: Renovar, 2002, p. 426.

99 A ponderação subordina os direitos fundamentais a uma "reserva de ponderação"; trata-se de método inconsistente pois traduz procedimento formal, não fornecendo pautas materiais vinculantes para a solução dos casos concretos, de modo que diversas pessoas podem chegar a diferentes resultados de peso e grau de afetação de um princípio; a ponderação atribui excessivo poder ao Judiciário em detrimento do Legislativo, na medida em que eles estariam autorizados a fazer escolhas políticas, implicando uma perda de legitimidade democrática no procedimento jurídico, já que os juízes não são eleitos. OLSEN, Ana Carolina Lopes. A Eficácia dos Direitos Fundamentais Sociais Frente à Reserva do Possível. 390 f. Dissertação (mestrado) - Universidade Federal do Paraná, Setor de Ciências Jurídicas, Programa de Pós Graduação em Direito. Defesa: Curitiba, 2006, p. 70-71.

${ }^{100}$ SARMENTO, Daniel. op. cit. (2009), p. 139.

${ }^{101}$ BARROSO, Luís Roberto. op. cit. (2013), p. 333.
} 


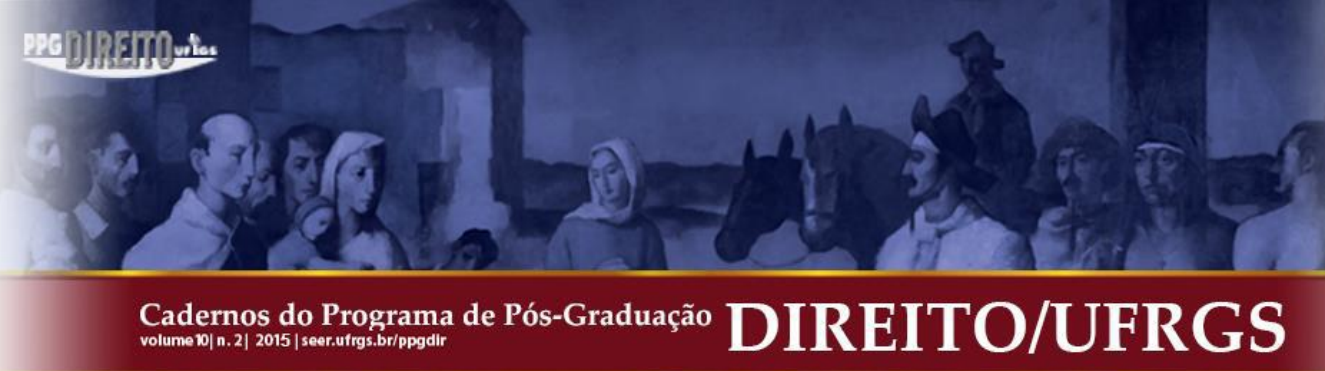

judicial parece um equívoco, principalmente diante da coexistência de várias visões de mundo disputando espaço." 102

Ademais, Lenio Luiz STRECK critica o chamado "solipsismo judicial", ${ }^{103}$ isto é, as decisões conforme a consciência do julgador, defendendo a tese de que as decisões judiciais não devem ser tomadas a partir de critérios pessoais, a partir da consciência psicologista. ${ }^{104}$

O referido doutrinador destaca que se tem uma nova ideologia teorética, visto que no lugar do juiz "boca da lei" colocou-se um juiz que julga conforme a sua consciência ou conforme os valores que "descobre” por trás dos textos jurídicos. Assim, "do mito do dado, espécie de objetivismo filosófico, passou-se ao império do subjetivismo, caracterizado pelo poder discricionário dos juízes. Como responsáveis [...] podem ser elencados o neoconstitucionalismo, de cariz axiologista, e as teorias da argumentação jurídica." 105

Contudo, o ponto de partida para um debate acerca da racionalidade de qualquer forma de interpretação e aplicação do Direito é a percepção de que "não é possível buscar uma racionalidade que exclua, por completo, qualquer subjetividade nessas atividades." "106

Para Paulo Ricardo SCHIER, o processo de ponderação é subjetivo, mas nem por isso ele deve ser arbitrário. Assim sendo, "o Direito demanda uma certa racionalidade e, no processo sua racionalização, há que se conter a subjetividade pura e simples.",107

Além disso, o uso da ponderação como princípio decorre de um fenômeno peculiar à realidade brasileira, denominado panprincipiologismo, ou seja, a proliferação de princípios. ${ }^{108}$

Conforme Lenio Luiz STRECK, ele “[...] faz com que, a pretexto de aplicar princípios constitucionais, haja uma proliferação descontrolada de enunciados para resolver determinados problemas concretos". 109

\footnotetext{
${ }^{102}$ SARMENTO, Daniel. Interpretação Constitucional, Pré-compreensão e Capacidades Institucionais do Intérprete. In: SOUZA NETO, Cláudio Pereira de; SARMENTO, Daniel; BINENBOJM, Gustavo (coords.). Vinte Anos da Constituição Federal de 1988. Rio de Janeiro: Lumen Juris, 2009, p. 312.

${ }^{103}$ Solipsismo (do latim solu <só> + ipse <mesmo>). Significa costume de quem é solitário, ou seja, de que se fecha em si mesmo. Doutrina que sustenta ser o eu individual toda a realidade. DINIZ, Maria Helena. Dicionário Jurídico. 2. ed. v. 4. São Paulo: Saraiva, 2005, p. 510.

${ }^{104}$ STRECK, Lenio Luiz. Decido conforme a minha Consciência? 4. ed. Porto Alegre: Livraria do Advogado, 2013, p. 117.

${ }^{105}$ STRECK, Lenio Luiz. Jurisdição Constitucional e Decisão Jurídica. 4. ed. São Paulo: Revista dos Tribunais, 2014, p. 933.

${ }^{106}$ SILVA, Virgílio Afonso da. Direitos Fundamentais: Conteúdo Essencial, Restrições e Eficácia. 2. ed. São Paulo: Malheiros, 2011, p. 146-147.

${ }^{107}$ SCHIER, Paulo Ricardo. op. cit. (2007), p. 260.

${ }^{108}$ STRECK, Lenio Luiz. O Panprincipiologismo e o Problema da Fragilidade da Discussão da Teoria da Norma. Terrae Brasilis. Jurispoiesis, Rio de Janeiro, v. 1, 2012, p. 343.

${ }^{109}$ STRECK, Lenio Luiz. Verdade e Consenso: Constituição, Hermenêutica e Teorias Discursivas. 4. ed. São Paulo: Saraiva, 2011, p. 50.
} 


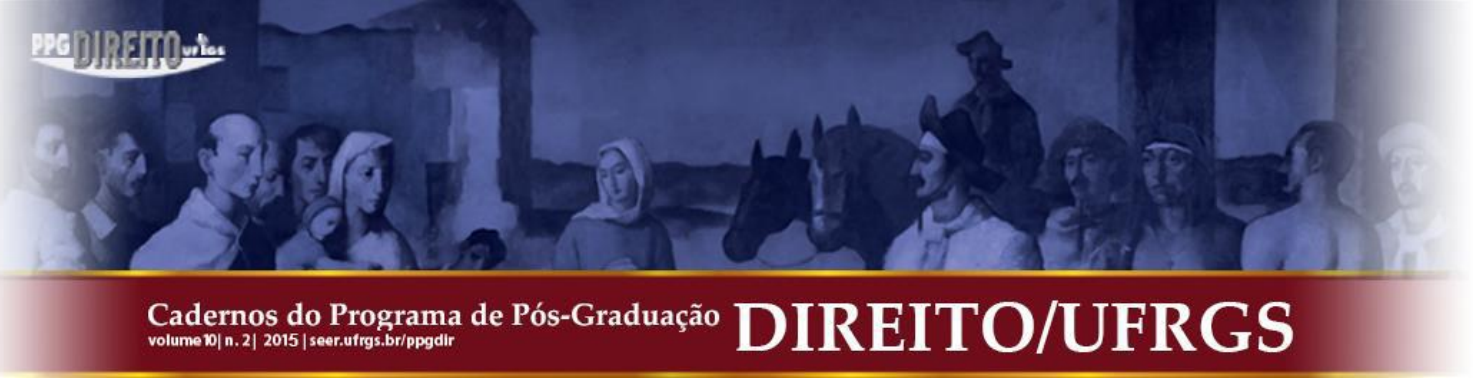

Daniel SARMENTO explica que "instalou-se um ambiente intelectual no Brasil que aplaude e valoriza as decisões principiológicas, e não aprecia tanto aquelas calcadas em regras legais, que são vistas como burocráticas ou positivistas."

Nesta perspectiva, Paulo Ricardo SCHIER trata dos excessos da dogmática constitucional principialista explicando que "é preciso tomar certas cautelas para não alargar os horizontes da principiologia constitucional a ponto de afirmar que toda e qualquer norma pode ser ponderada ou relativizada."111

Com efeito, "muitos juízes, deslumbrados diante dos princípios, e da possibilidade de, através deles, buscarem a justiça, passaram a negligenciar do seu dever de fundamentar racionalmente os seus julgamentos. Esta "euforia" com os princípios abriu um espaço muito maior para o decisionismo judicial. E ele afirma que a outra face da moeda é o lado do decisionismo e do oba-oba." 112

Dessa forma, há dois pontos que se fossem "levados a sério" poderiam minimizar certos vícios que o pós-positivismo anda resvalando no país:

\begin{abstract}
O primeiro deles seria a valorização da argumentação jurídica e da racionalidade prática, pois as decisões adotadas devem ser devidamente justificadas demonstrando que o resultado alcançado é o mais adequado à ordem jurídica e às peculiaridades do caso. Assim, a fundamentação das decisões judiciais, muito mais do que um requisito formal da sua validade, é um pressuposto da sua legitimidade no âmbito do Estado Democrático de Direito. O outro, consiste na valorização e respeito também das regras jurídicas. ${ }^{113}$
\end{abstract}

Neste contexto, destaca-se a teoria da argumentação jurídica, vista como uma forma de demonstrar a correção da decisão que pondera princípios jurídicos. ${ }^{114}$

A partir da consciência de que a lógica formal é insuficiente para a justificação de enunciados jurídicos nasce a teoria da argumentação jurídica que intenta minimizar a subjetividade das interpretações a serem procedidas pelos aplicadores do Direito. ${ }^{115}$

A teoria da argumentação jurídica está no âmbito da teoria do discurso, e além deste papel questionador do positivismo jurídico, busca demonstrar a possibilidade e a validade da

\footnotetext{
${ }^{110}$ SARMENTO, Daniel. op. cit. (2009), p. 139.

${ }^{111}$ SCHIER, Paulo Ricardo. op. cit. (2014), p. 48-49.

112 SARMENTO, Daniel. op. cit. (2007), p. 142.

${ }^{113}$ Ibidem, p. 142-143.

${ }^{114}$ ALEXY, Robert. Teoria da Argumentação Jurídica. 2. ed. Tradução de Zilda Hutchinson Schild Silva. São Paulo: Landy, 2005, p. 181- 217 e 272.

115 DUARTE, Luciana Gaspar Melquíades; CARVALHO, Caroline Pessoa de. Aplicabilidade da Teoria da Argumentação Jurídica de Robert Alexy nas Decisões Judiciais. Direitos Fundamentais \& Justiça, Porto Alegre, ano 6, n. 21, out./dez. 2012, p. 130.
} 


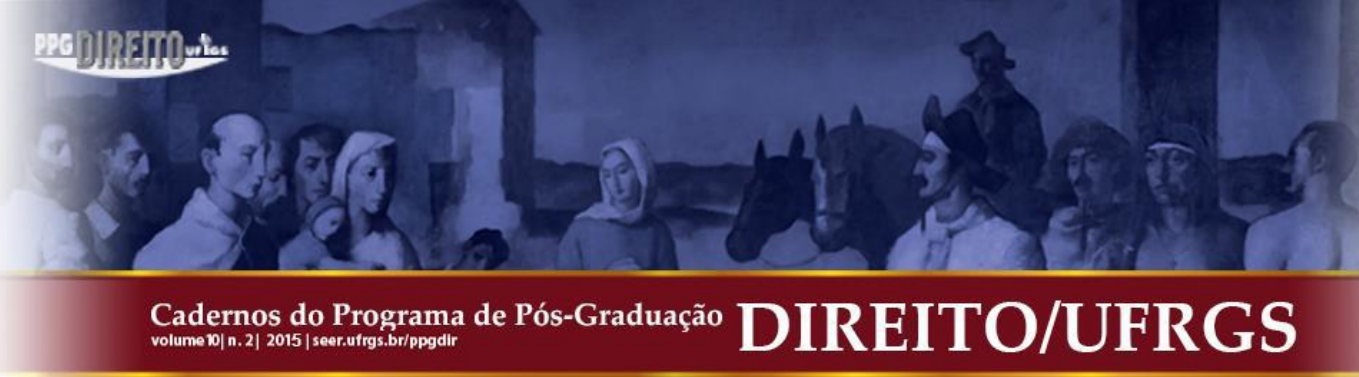

direito fundamental." 121 O art. 93, IX da Constituição Federal trata do dever de fundamentação das decisões judiciais. ${ }^{122}$

Daí surgem as propostas para orientar a argumentação jurídica, nelas destacam-se a necessidade de fundamentação com elementos da ordem jurídica que embasem a decisão.

Luís Roberto BARROSO aponta três parâmetros para informar a argumentação jurídica:

\begin{abstract}
a) a necessidade de fundamentação com elementos da ordem jurídica que embasem tal ou qual decisão, pois não bastam o senso comum e o sentido pessoal de justiça; b) a necessidade de respeito à integridade do sistema (unidade, continuidade e coerência da ordem jurídica); c) o peso (relativo) a ser dado às consequências concretas da decisão visto que o juiz não pode ser indiferente à repercussão de sua atuação sobre o mundo real, a vida das instituições, do Estado e das pessoas. ${ }^{123}$
\end{abstract}

Outrossim, Ana Paula de BARCELLOS formula parâmetros capazes de orientar e balizar as decisões do intérprete no emprego da ponderação, que devem ser aplicados de forma sequencial e geral (aplicáveis a qualquer conflito normativo): “(i) as regras têm preferência sobre os princípios; e (ii) as normas que realizam diretamente os direitos fundamentais dos indivíduos têm preferência sobre aquelas que estão relacionadas com esse fim apenas de forma indireta.” Dessa forma, ela pretende conferir a técnica da ponderação maior juridicidade e racionalidade. ${ }^{124}$

Nesse contexto, "não é possível falar em resposta correta para os problemas jurídicos, mas sim em soluções argumentativamente racionais e plausíveis." Assim sendo, deve-se demonstrar de forma lógica que determinada decisão é a que mais adequadamente realiza os fins constitucionais no caso concreto. ${ }^{125}$

Ainda, para tornar o sistema que emprega essa técnica mais racional, mister se faz aprimorar a consistência metodológica da técnica da ponderação e construir parâmetros jurídicos capazes de orientar seu emprego. Logo, “a ordenação objetiva e clara das etapas a

\footnotetext{
${ }^{121}$ STRECK, Lenio Luiz. op. cit. (2014), p. 931.

122 "Art. 93: [...]

IX todos os julgamentos dos órgãos do Poder Judiciário serão públicos, e fundamentadas todas as decisões, sob pena de nulidade, podendo a lei limitar a presença, em determinados atos, às próprias partes e a seus advogados, ou somente a estes, em casos nos quais a preservação do direito à intimidade do interessado no sigilo não prejudique o interesse público à informação."

${ }^{123}$ BARROSO, Luís Roberto. op. cit. (2013), p. 369-371.

${ }^{124}$ BARCELLOS, Ana Paula de. op. cit., p. 15-20.

${ }^{125}$ BARROSO, Luís Roberto. op. cit. (2013), p. 373.
} 


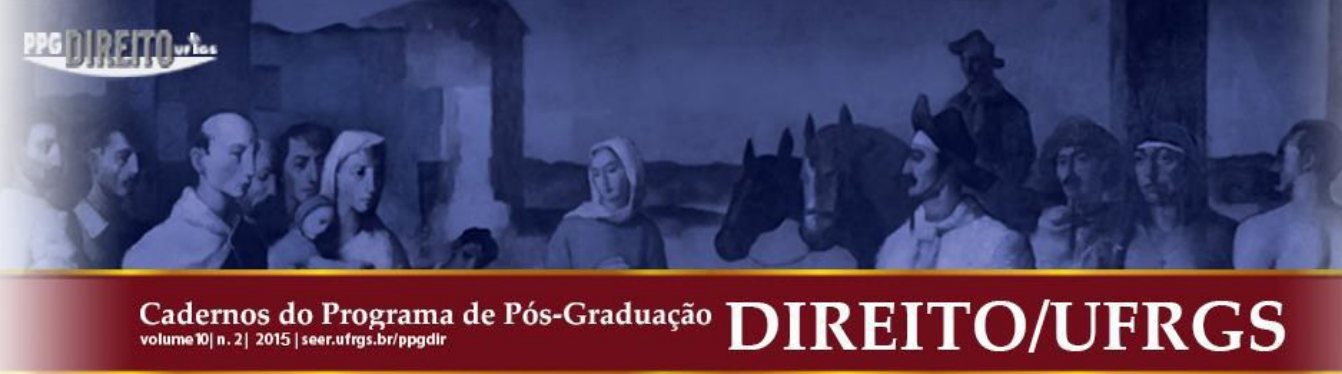

excludente do modelo de regras. Logo, é necessário um modelo misto fundado tanto em princípios como em regras que desempenham funções distintas no ordenamento jurídico;

4. Por fim, tratou-se dos excessos da dogmática constitucional principialista. Foi discutido se o modelo de princípios gera um déficit de racionalidade no Direito permitindo uma abertura ao decisionismo. Assim, foi examinada a ponderação de bens, que se constitui como um critério apto a oferecer a solução adequada às colisões de normas revestidas de princípios. Entendeu-se que o processo de ponderação não deve ser arbitrário. Ainda, o uso da ponderação como princípio decorre de um fenômeno peculiar à realidade brasileira, denominado panprincipiologismo (proliferação de princípios). Há doutrinadores que afirmam que juízes, deslumbrados diante dos princípios, passaram a negligenciar do seu dever de fundamentar racionalmente os seus julgamentos, abrindo espaço para o decisionismo judicial. Por isso, foi analisada a teoria da argumentação jurídica elaborada por Robert ALEXY, que busca combater o argumento de arbitrariedade das decisões com uma abordagem intersubjetiva. Nesse contexto, é preciso haver racionalidade (vinculação ao sistema jurídico em vigor e responder por que uma determinada solução deve ser adotada e não outra - ônus argumentativo) e justificação (necessidade de explicitar as razões pelas quais uma decisão foi tomada dentre outras possíveis). Portanto, é preciso que sejam valorizadas a argumentação jurídica e a racionalidade prática, pois as decisões adotadas devem ser devidamente justificadas demonstrando que o resultado alcançado é o mais adequado à ordem jurídica e às peculiaridades do caso.

\section{REFERÊNCIAS}

ADORNO, Theodor W.; HORKHEIMER, Max. Dialética do Esclarecimento. Tradução de Guido de Almeida. Rio de Janeiro: Jorge Zahar, 1985.

ALEXY, Robert. Teoria da Argumentação Jurídica. 2. ed. Tradução de Zilda Hutchinson Schild Silva. São Paulo: Landy, 2005.

. Teoria dos Direitos Fundamentais. 2. ed. Tradução de Virgílio Afonso da Silva. São Paulo: Malheiros, 2011.

ÁVILA, Humberto. "Neoconstitucionalismo": Entre a "Ciência do Direito" e o "Direito da Ciência". In: SOUZA NETO, Cláudio Pereira de; SARMENTO, Daniel; BINENBOJM, 


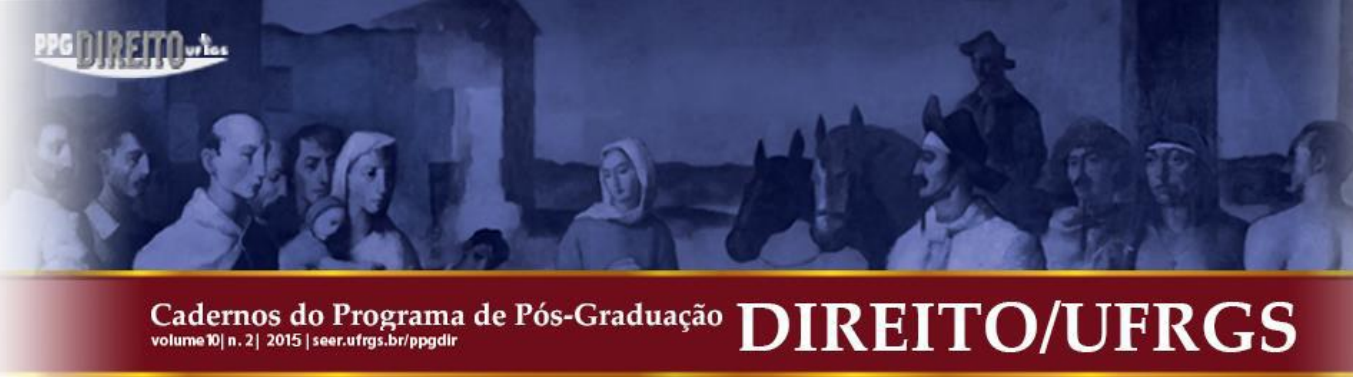

Gustavo (coords.). Vinte Anos da Constituição Federal de 1988. Rio de Janeiro: Lumen Juris, 2009, p. 187-202.

BACON, Francis. Novum Organum ou Verdadeiras Indicações Acerca da Interpretação da Natureza. Tradução de José Aluysio Reis de Andrade. Disponível em: http://www.dominiopublico.gov.br/download/texto/cv000047.pdf. Acesso em: 10 out. 2015.

BARCELlOS, Ana Paula de. Ponderação, Racionalidade e Atividade Jurisdicional. Rio de Janeiro: Renovar, 2005.

BARROSO, Luís Roberto. Neoconstitucionalismo e a Constitucionalização do Direito: O Triunfo Tardio do Direito Constitucional no Brasil. Jus Navigandi, Teresina, ano 9, n. 851, 1 nov. 2005. Disponível em: http://jus2.uol.com.br/doutrina/texto.asp?id=7547. Acesso em: 10 fev. 2015.

Curso de Direito Constitucional Contemporâneo: Os Conceitos Fundamentais e a Construção do Novo Modelo. São Paulo: Saraiva, 2013.

BARROSO, Luis Roberto; BARCELLOS, Ana Paula de. A Nova Interpretação Constitucional: Ponderação, Argumentação e Papel dos Princípios. In: LEITE: George Salomão (org.). Dos Princípios Constitucionais. Considerações em Torno das Normas Principiológicas da Constituição. São Paulo: Malheiros: 2003.

BAUMAN, Zygmunt. Modernidade e Ambivalência. Tradução de Marcus Penchel. Rio de Janeiro: Jorge Zahar Editor, 1999.

BORGES, Juliano. A Dialética do Esclarecimento, de Thodor Adorno e Max Horkheimer. Revista Estudos Políticos, Rio de Janeiro, n. 2, 2011/01, p. 103-106.

CARBONELL, Miguel. Neoconstitucionalismo(s). Madrid: Trotta, 2003.

DIMOULIS, Dimitri. Uma Visão Crítica do Neoconstitucionalimo. In: SALOMÃO, George Leite; SALOMÃO, Glauco Leite (coords.). Constituição e Efetividade Constitucional. Salvador: Juspodivm, 2008.

DINIZ, Maria Helena. Dicionário Jurídico. 2. ed. v. 4. São Paulo: Saraiva, 2005. 


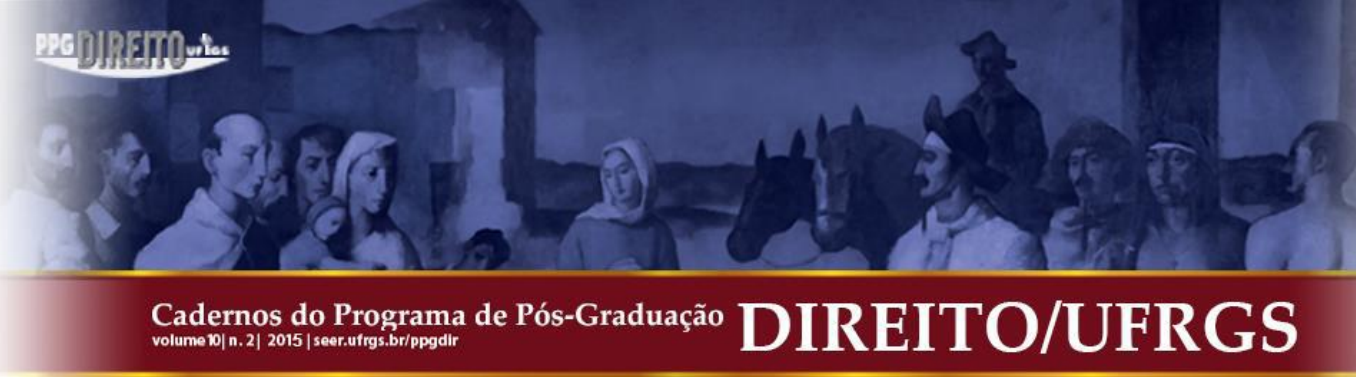

DUARTE, Luciana Gaspar Melquíades; CARVALHO, Caroline Pessoa de. Aplicabilidade da Teoria da Argumentação Jurídica de Robert Alexy nas Decisões Judiciais. Direitos Fundamentais \& Justiça, Porto Alegre, ano 6, n. 21, out./dez. 2012, p. 124-144.

DWORKIN, Ronald. El Concepto y la Validez del Derecho y Outros Ensayos. Barcelona: Gedisa, 2004.

2002.

. Levando os Direitos a Sério. Tradução de Nelson Boeira. São Paulo: Martins Fontes,

ENTERRÍA, Eduardo Garcia de. La Constitución como Norma y el Tribunal Constitucional. 3. ed. Madrid: Civitas, 1983.

FONSECA, Ricardo Marcelo. Introdução Teórica à História do Direito. Curitiba: Juruá, 2012.

HESPANHA, António Manuel. A Cultura Jurídica Europeia: Síntese de um Milênio.

Coimbra: Almedina, 2012.

JUSTEN FILHO, Marçal. Curso de Direito Administrativo. 5. ed. São Paulo: Saraiva, 2010.

KANT, Imamnuel. Resposta à Pergunta: Que é "Esclarecimento" (Aufklärung)? Textos Seletos. Tradução de Floriano de Sousa Fernandes. 2. ed. Petrópolis: Vozes, 1985, p. 100-117.

KELSEN, Hans. Teoria Pura do Direito. Tradução de João Baptista Machado. 8. ed. São Paulo: Martins Fontes, 2009.

MAIA, Antonio Cavalcanti. Nos Vinte Anos da Carta Cidadã: Do Pós-positivismo ao Neoconstitucionalismo. In: SOUZA NETO, Cláudio Pereira de; SARMENTO, Daniel; BINENBOJM, Gustavo (coords.). Vinte Anos da Constituição Federal de 1988. Rio de Janeiro: Lumen Juris, 2009, p. 117-168.

MORIN, Edgar. Ciência com Consciência. 8. ed. Tradução de Maria D. Alexandre e Maria Alice Sampaio Dória. Rio de Janeiro: Bertrand Brasil, 2005.

MULLER, Friedrich. Métodos de Trabalho do Direito Constitucional. Tradução de Peter Naumann. São Paulo: Max Limonad, 2000. 


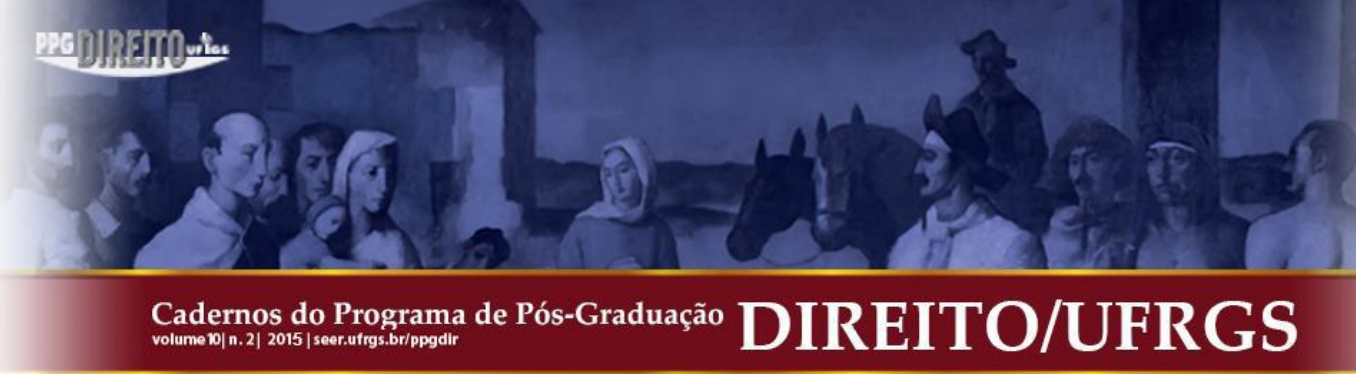

Tesis acerca de la Estrutura de las Normas Jurídicas. Tradução de Luis Villacorta Mancebo. Madrid: Centro de Estudios Constitucionales, 1989.

OLSEN, Ana Carolina Lopes. A Eficácia dos Direitos Fundamentais Sociais Frente à Reserva do Possível. 390 f. Dissertação (mestrado) - Universidade Federal do Paraná, Setor de Ciências Jurídicas, Programa de Pós Graduação em Direito. Defesa: Curitiba, 2006.

POZZOLlO, Susanna. Um Constitucionalismo Ambíguo. In: CARBONELL, Miguel. Neoconstitucionalismo(s). Madrid: Trotta, 2003.

PRIETO SANCHÍS, Luis. Justicia Constitucional y Derechos Fundamentales. Madrid: Trotta, 2003.

RAMOS, Écio Oto; POZZOLO, Susanna. Neoconstitucionalismo e Positivismo Jurídico: As Faces da Teoria do Direito em Tempos de Interpretação Moral da Constituição. São Paulo: Landy Editora, 2006.

SANTOS, Boaventura de Souza. A Crítica da Razão Indolente: Contra o Desperdício da Experiência. 4. ed. v. 1. São Paulo, Cortez, 2002.

SARMENTO, Daniel. Ubiquidade Constitucional: Os Dois Lados da Moeda. In: SOUZA NETO, Cláudio Pereira; SARMENTO, Daniel (orgs.). A Constitucionalização do Direito: Fundamentos Teóricos e Aplicações Específicas. Rio de Janeiro: Lúmen Júris, 2007, p. 113 148.

. O Neoconstitucionalismo no Brasil: Riscos e Possibilidades. In: SARMENTO, Daniel (coord.). Filosofia e Teoria Constitucional Contemporânea. Rio de Janeiro: Lúmen Júris, 2009, p. 113-146.

Interpretação Constitucional, Pré-compreensão e Capacidades Institucionais do Intérprete. In: SOUZA NETO, Cláudio Pereira de; SARMENTO, Daniel; BINENBOJM, Gustavo (coords.). Vinte Anos da Constituição Federal de 1988. Rio de Janeiro: Lumen Juris, 2009, p. 311-322.

SCHIER, Paulo Ricardo. Novos Desafios da Filtragem Constitucional no Momento do Neoconstitucionalismo. In: NETO, Cláudio Pereira de Souza; SARMENTO, Daniel (coords.). 


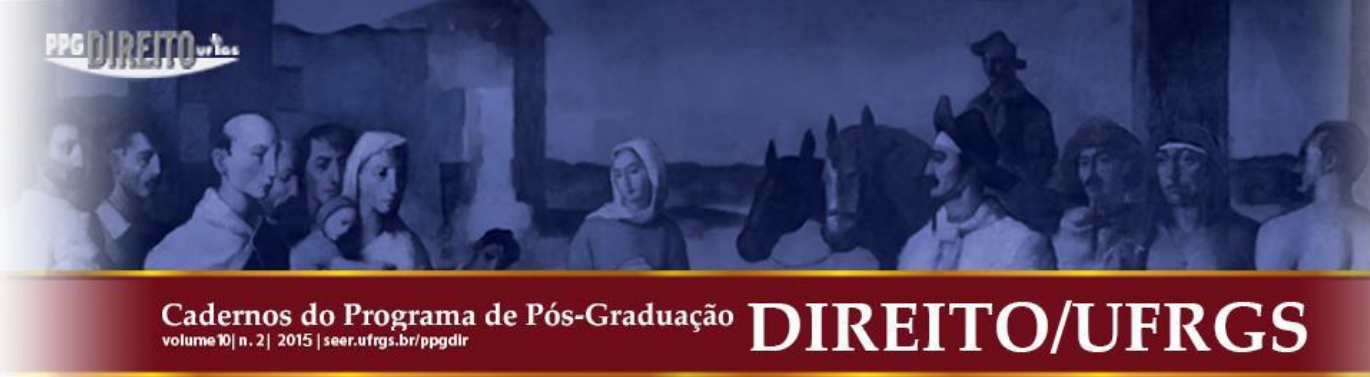

A Constitucionalização do Direito: Fundamentos Teóricos e Aplicações Específicas. Rio de Janeiro: Lumen Juris, 2007, p. 251-270.

Direito Constitucional: Anotações Nucleares. 8. tir. Curitiba: Juruá, 2008.

. Constitucionalização do Direito no Contexto da Constituição de 1988. In: CLÈVE, Clèmerson Merlin. (Org.). Direito Constitucional Brasileiro. São Paulo: Revista dos Tribunais, 2014, p. 43-60.

SILVA, Virgílio Afonso da. Direitos Fundamentais: Conteúdo Essencial, Restrições e Eficácia. 2. ed. São Paulo: Malheiros, 2011.

STRECK, Lenio Luiz. Decido conforme a minha Consciência? 4. ed. Porto Alegre: Livraria do Advogado, 2013.

Tribunais, 2014.

Jurisdição Constitucional e Decisão Jurídica. 4. ed. São Paulo: Revista dos O Panprincipiologismo e o Problema da Fragilidade da Discussão da Teoria da Norma. Terrae Brasilis. Jurispoiesis, Rio de Janeiro, v. 1, 2012, p. 337-354.

. Verdade e Consenso: Constituição, Hermenêutica e Teorias Discursivas. 4. ed. São Paulo: Saraiva, 2011.

TOLEDO, Cláudia. Teoria da Argumentação Jurídica. Veredas do Direito, Belo Horizonte, v. 2, n. 3, jan./jun. 2005, p. 47-65.

TORRES, Ricardo Lobo. A Legitimação dos Direitos Humanos e os Princípios da Ponderação e da Razoabilidade. In: TORRES, Ricardo Lobo. (coord.). Legitimação dos Direitos Humanos. Rio de Janeiro: Renovar, 2002, p. 837-848.

ZAGREBELSKY, Gustavo. El Derecho Dúctil. Madrid: Trotta, 2007.

Submissão: 24/09/2015 Aceito para Publicação: 27/10/2015 
